\title{
理論之論説＼cjkstart東洋医学脈診法の機械化
}

$\begin{array}{lllr}\text { 高島 } & \text { 充 }^{1)} & \text { 長屋 } & \text { 健 }^{1)} \\ \text { 菊名 } & \text { 岡 }^{2)} & \text { 松多 } & \text { 邦雄 }^{2)}\end{array}$

\section{Development of New Apparatus for Oriental Pulse Diagnosis}

\author{
Mitsuru TAKASHIMA ${ }^{1)}$ Ken NAGAYA ${ }^{1)}$ \\ Tsuyoshi KIKUNA $^{2)}$ Kunio MATSUTA ${ }^{2)}$
}

1) $\mathrm{Ph}$ D.s, Sony Corporation Research Institute of Wisłon, 6-7-35, Kitashinagawa, Shinagawa-Ku, Tokyo 141, Japan

2) M. D.s, Matsuta Clinic, Tokyo, Japan

\begin{abstract}
The authors developed an innovative apparatus for analyzing pulse waves which uses a new type of pulse sensor. Based on the principles of Oriental medicine, this pulse wave machine takes measurements from the radial artery to determine the subject's state of health. Three sensors were used in place of the fingers to assess changes in the pulse wave pattern induced by reducing pressure in a cuff. A cuff with sliding components proved to be the most suitable in that it was less likely to be affected by the subject's movements. Using this type of cuff, the authors were able to observe the pulse-wave amplitude as cuff pressure was reduced after the blood flow had been stopped. The signal in each channel changed according to the degree of pressure reduction, and a characteristic pulse wave pattern was produced. This pattern enabled the authors to observe how the pulse behaved under each sensor and how the pulse wave changed. The authors were also able to observe and measure the condition velocity as the artery opened as well as assess the condition of the palmer arterial arch.
\end{abstract}

Key words: Blood pressure, cuff, pressure sensor, pressure reduction, radial artery

Nihon Toyo Igaku Zasshi (Japanese Journal of Oriental Medicine), 47, 635-643, 1997 (Accepted 1 Jul., 1996)

\section{緒 言}

東洋医学のみならず，世界の指による脈診法は 第二，三，四指の 3 本をセンサーとして用い，橈 骨動脈を主な測定対象としている。これは，脈が 触れ易い部位であることのほかに，橈骨を軸とし
て体表からの指による押し圧で容易に，かつ正確 に血流を制限できるからである1”。すでに国内外 で，圧力センサーを用いて指の触覚を波形情報に 置換えた検討例がある2 ${ }^{2)}$ 。我々は，人の触覚に 似せた指先大の微分型圧力センサーを開発し，3 個を等間隔に 1 列に並べ, 圧迫部の曲率に追従可

1）替, ソニー株式会社 生命情報研究所, 東京, $\bar{\top} 141$ 品川区北品川6-7-35

2）医，松多医院，東京

[1996年 7 月 1 日受理] 


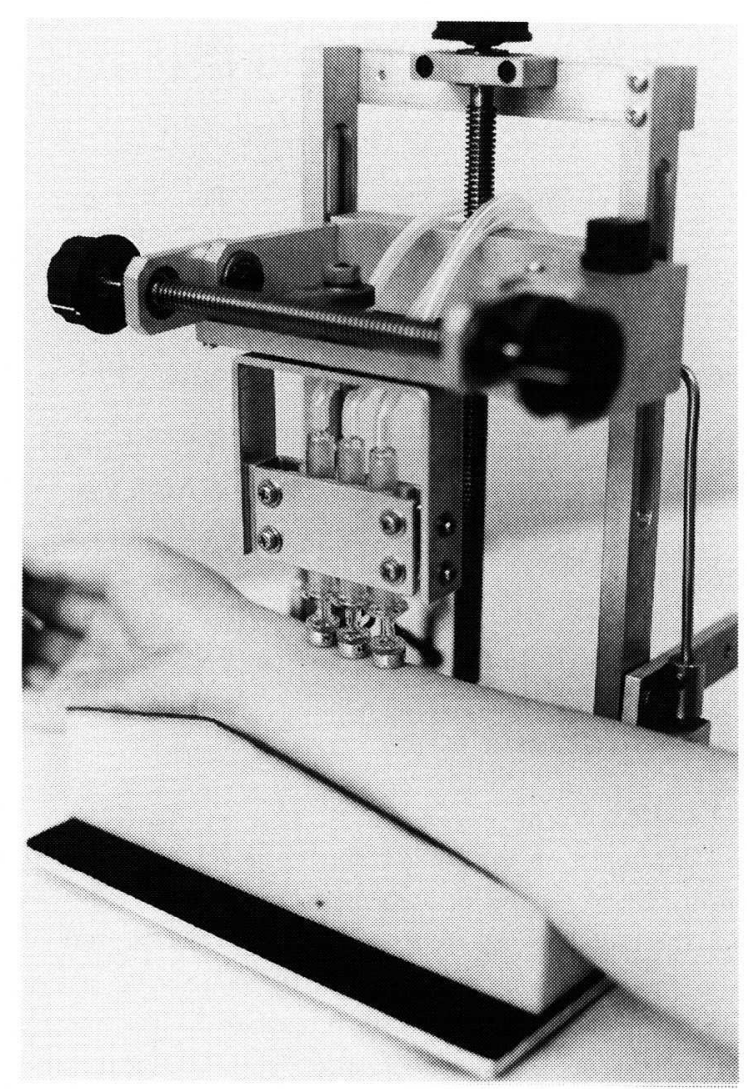

図 13 連ピストン式加圧装置

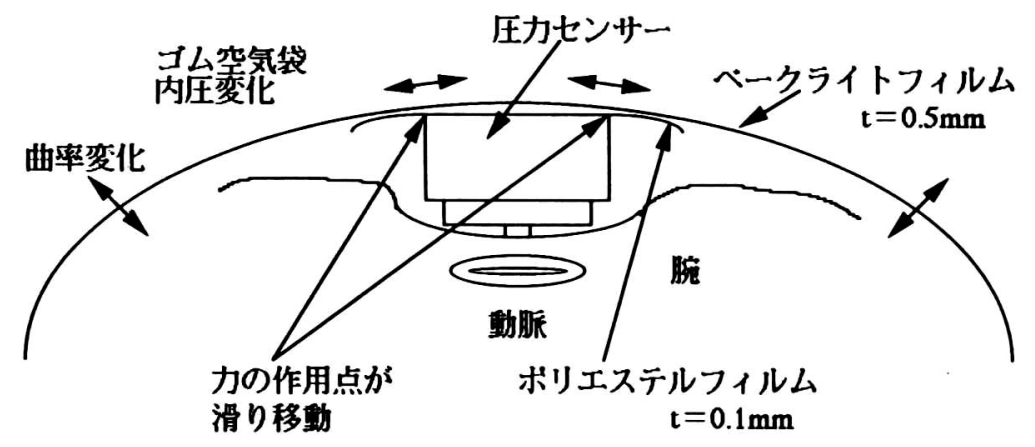

図 2 滑り機構付マンシェットによる圧力センサー圧迫概念図

能な特殊マンシェット方式でセンサー圧迫圧を得 て,この圧迫圧の連続減哀時の信号から検討する ことをすでに提案しだ)。これは 1 本の橈骨動脈 部に皮虐上から等間隔, 等圧, 血流に垂直に 3 個 の圧力センサーを設けた場合, 得られる科学的情
報をまず捕え，その結果から東洋医学脈診法を推 察するという逆の見方である。本稿では，この計 測システムをより詳細に述べるとともに, 高圧捕 捉で得られる情報に焦点を当て検討した結果を示 す。 

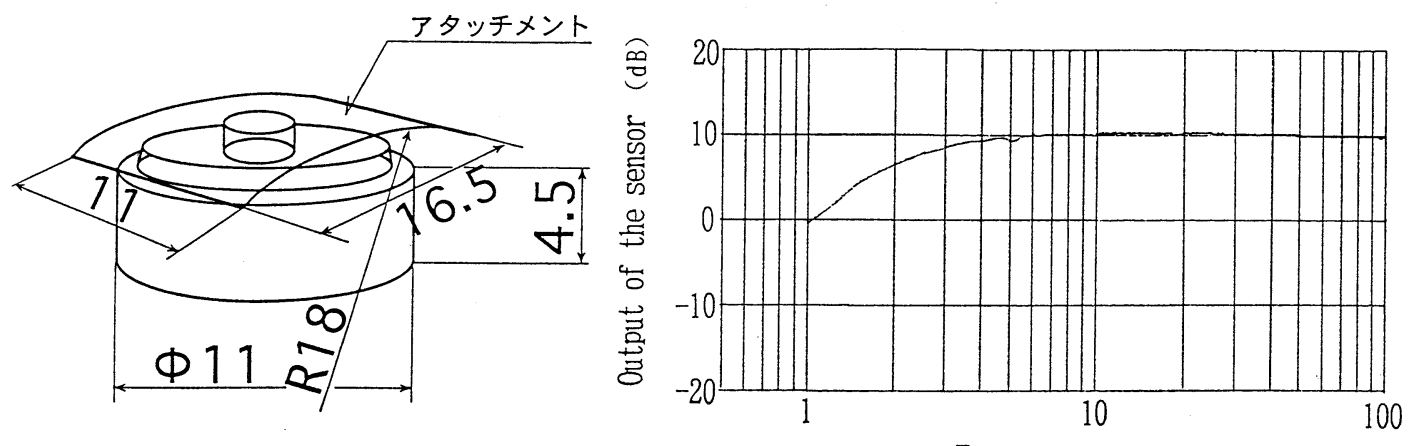

Frequency $(\mathrm{Hz})$

図 3 圧力センサー形状図特よびゲイン周波数特性
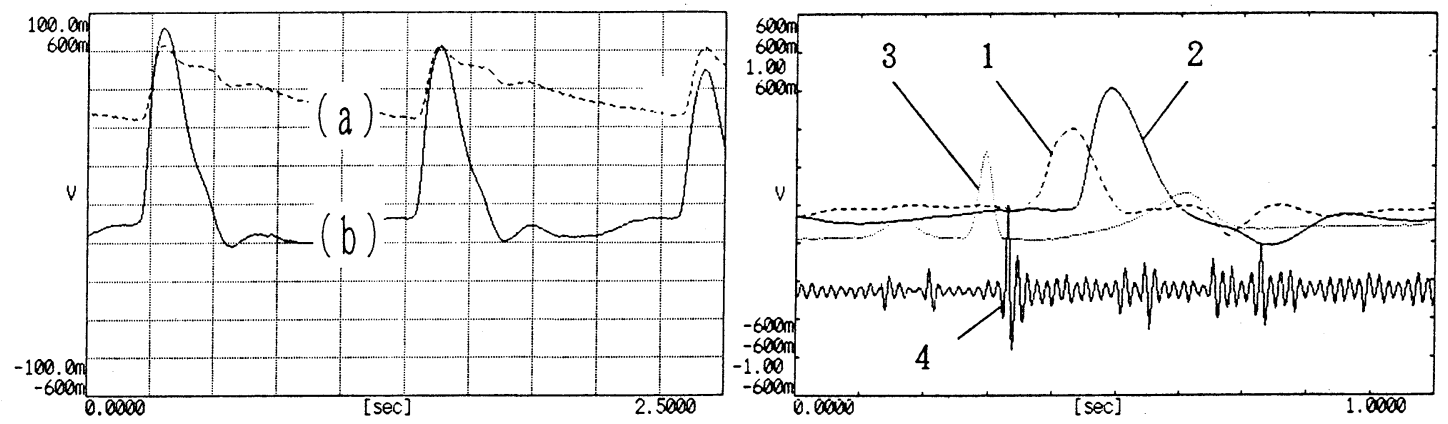

図 4 同一橈骨動脈での圧脈波(a)とセンサー出力波形(b)

(1)頸動脈，(2)橈骨動脈からのセンサー出力波形と(3)心電図，(4)心音図

\section{方 法}

1. 橈骨動脈圧迫法

指による脈診法は 3 指を被験者の橈骨茎状突起 近傍の動脈上飞置き, 親指を手首の甲側とし, 手 首を挟み込む形で圧迫を加える。我々は医師がな にげなく動脈を探す動作を分析し，まず図１のよ らな回転 2 軸, 直線 1 軸のピストン式を作製し

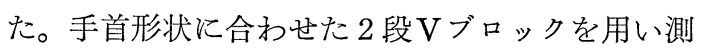
定部の固定を行うと共に体動を抑えることとし た。しかし，体動信号を入れないためには被験者 の全身に強い緊張を要求する結果となり, 臨床現 場での応用には至らなかった。また，血管側圧が ピストンの微小偏位をもたらし，それがピストン 摺動ノイズとしてセンサー信号に入り込む問題も あった。体動のある中で安定に脈波信号を捕える ためには腕の周辺のみで測定部分を構成し, 腕が
自由になる圧迫法を作り出す必要が出た。そし て，尺骨動脈に圧迫が及ばないよう金属板を入れ たマンシェットを考案し，ゴム袋を直接にセンサ 一列底面へ当てず，プラスチックフィルム製滑り 板を介して各センサー底面にピンポイントで 2 点 つう力を加える方法とした。これにより，異なる 腕の形状や，高圧から低圧までの曲率変化に対し ても各センサー底面が滑りながら追従するの之同 時に，3 個のセンサーは常に等しい力で皮膚上を 押すことが可能となった（図 2)。東洋医学の発 達地域や流派によって 3 指の力の強弱関係が微妙 に異なり ${ }^{6)}$ ，捕捉圧を定量的に取り扱うことは困 難である。充分な高圧圧迫（血流が完全に止まる 強い押し圧）から低圧圧迫（マンシェット内压が ほぼ0）となるまでの全ての信号をメモリーし， 後の検索から波形情報の最適分析ポイントを選び 出すことによって脈誩法を推定することとした。 



図 5 本システム（脈波計測装置 EPG-1）全体像およびブロック図

この方法によれば,メモリーされた中に必ず全て の脈診の捕捉ポイントが残り，検討できることと なる。

2. 圧力センサー

排気によるマンシェット内圧変化は圧力センサ 一に加わる力の変化でもあり, 静圧型のセンサー では, 脈波の信号が内圧変化の信号に重疊されて 出力される。センサーの押し圧が収縮期血圧と平 衡するには皮膚上に $100 \mathrm{~g} / \mathrm{cm}^{2}$ 以上の力を加える 必要があり，微弱な脈波信号を重畳信号から取り 出すことは信号対雑音比 ( $\mathrm{S} / \mathrm{N}$ 比) の点から困難 となる。また, 被験者のわずかな体動が押し圧変 化をもたらし，長時間の基線動摇で悩まされる。
したがって，我々は小型の微分型圧力センサー (FET 内蔵バックェレクトレットコンデンサーマ イクロホン型）を専用に開発し，体動時にも 1 心 拍以内で復帰するよう時定数を $100 \mathrm{msec}$ 設定し た。また, 人の指は接触部全面に触覚があり, 通 常の円形膜振動型センサーの微小部分感度と異な る。センサー感圧面上の垂直部分感度が一定とな るよら図3のようにキノコ状のアタッチメントを 設けた。アタッチメント上の一部に動脈が走行し ていれば同一の脈波信号が得られることから，位 置ずれに対する再現性も高まり，同時に波形の立 ち上がりが鋭くなり 3 個のセンサー列（センサー 中心間距離 $13 \mathrm{~mm}$ ）での伝播時間計測が容易とな 


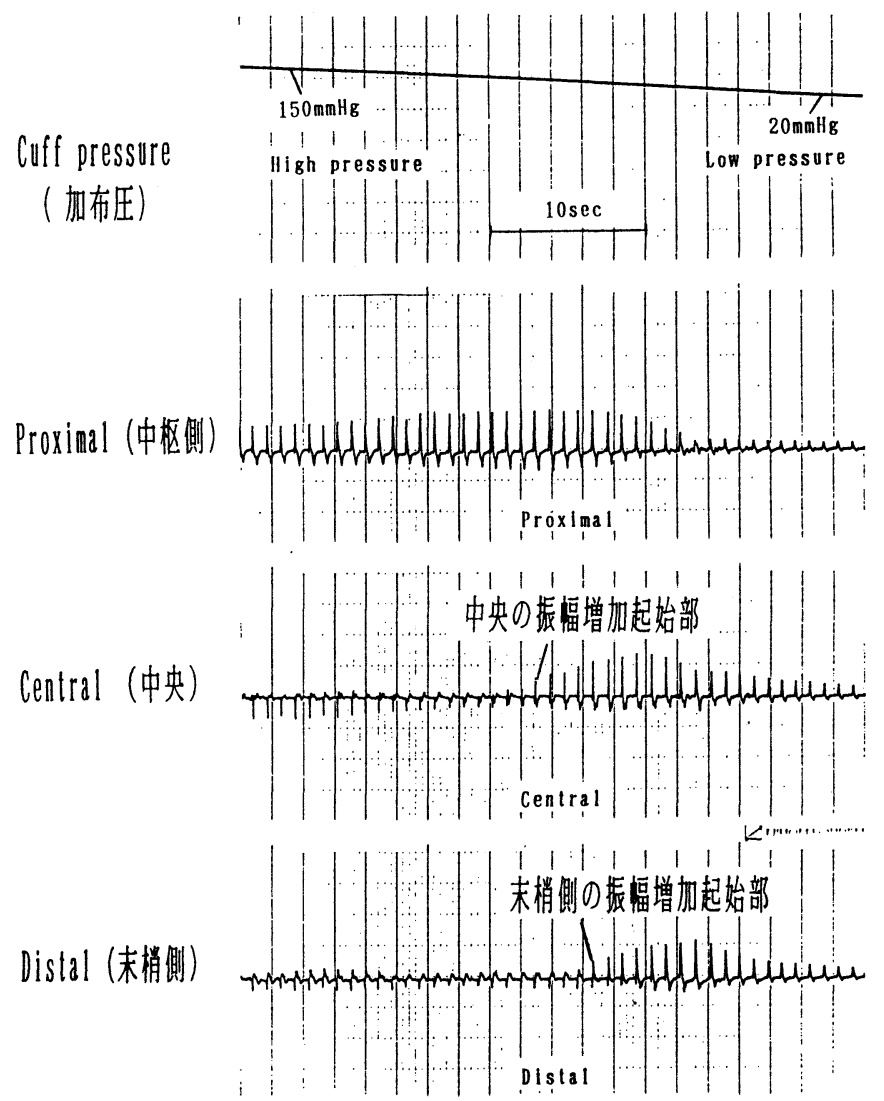

図 6 減圧過程に和ける 3 圧力センサー出力およびマンシェット圧電気信号

った。図 4 は同一橈骨動脈での压脈波（血圧波形） とセンサー出力拈よび心電図，心音図と同期観測 した頸動脈，橈骨動脈からのセンサー出力であ る。

3. 本体増幅部

図 5 亿装置全体を示す。本体は内部電池 2 個で 駆動され，個々のセンサーに独立した増幅器が設 けられ $23 \mathrm{mV} / \mathrm{gG}$ 電気出力（ここで $\mathrm{g}$ はグラム荷 重，Gは重力加速度）飞調整されている。また， 個々のセンサーの出力が確認できるようレベルメ 一タが設けてある。マンシェットの加圧はゴム球 による手動で，空気圧はデジタルマノメータにて 水銀柱表示され，同時に内部の半導体センサーが 電気信号に変換し， 3 個の圧力センサー出力と共 に出力される。マンシェット圧の連続減哀は, 内 部の等速度排気バルブで $200 \mathrm{mmHg} \sim 100 \mathrm{mmHg}$
間を約 30 秒と設定した。

4. 計測体位および位置

血圧情報も取り込むため橈骨動脈の場合，測定 部位は心臓の高さが望まれる。したがって計測体 位は座位，仰臥位があげられるが，付属ケーブル の摇れが大きなノイズとなるため仰臥位で測定し た。センサーの位置はマンシェットの一端を橈骨 茎状突起に合わせる巻き方とした。また，センサ 一列はマンシェットの中央部である必要があり, マンシェット幅に等しくなるようセンサー列フィ ルム両端に $16 \mathrm{~mm}$ オーバーハングを設けて位置ず れの目安とした。センサー感圧面が腕の橈側手根 屈腱や長掌腱に乗り上げると充分な止血ができな いため, 感圧面の縁が腱に $2 \sim 3 \mathrm{~mm}$ 離れて平行 となるようとサージカルテープであらかじめセン サー列を固定し，その上からマンシェットを巻き 

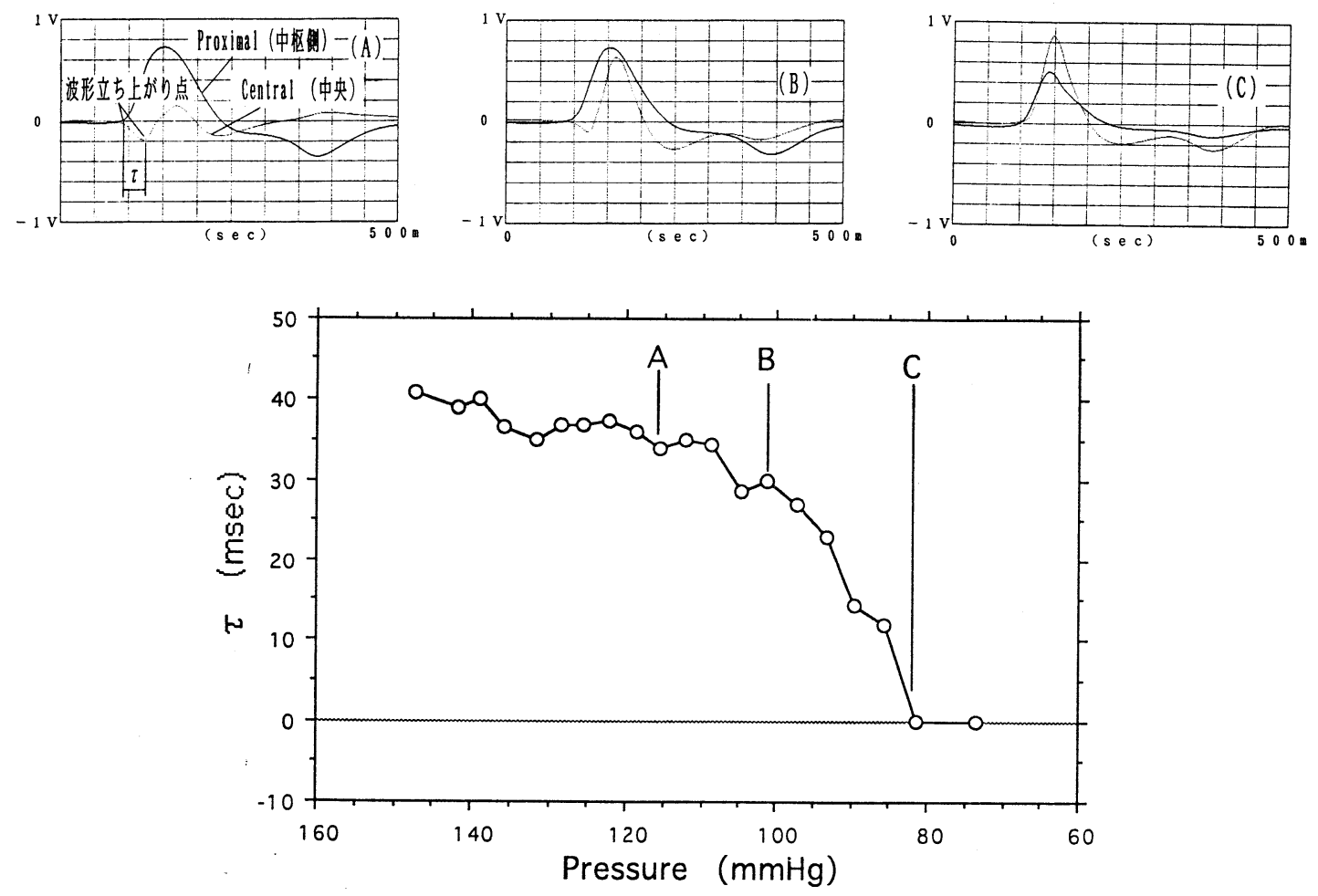

図 7 減圧過程に拈ける中枢, 中央側波形オーバーレイ(A), (B), (C) と 開口伝播時間差 $(\tau)$ の変化

上ける方法とした。

\section{5. 対象叔よび分析方法}

1991年より調査した約3000例の成人男女健常 群, 患者群の中から 20 60 歳屯での健常例 $\mathrm{N}=$ 400を無作為抽出し対象とした。

充分な高圧圧迫（血流が完全に止まる強い押し 圧）から低圧圧迫（マンシェット内圧がほぼ 0 ） となるまでの全ての信号の大まかな傾向を調べる ため, 本システム出力端子を心電計（日本光電工 業株式会社 ECG 6503）外部入力端子に接続し, 記録紙スピード $2.5 \mathrm{~mm} / \mathrm{sec} て ゙$ 観測した。

微分型圧力七ンサーの信号は皮膚上の圧迫压, 皮膚を介した動脈側圧の合力が微分されて出力さ れることから，振幅自体には注目せず振幅変化点 や時間差に注目し検討を行った。時間差計測は株 式会社小野測器ウェーブフォームアナライザー AF550を用い, 内蔵の $400 \mathrm{~Hz}$ ローパスフィルター を働かせ，時間軸フルスケール500 msec の波形拡
大と 3 チャンネル同期重ね書で計測した。

血圧変化は，片腕を心蔵の高さから上下させた とさの静水圧変化によって作り出した。脈波計測 部の血圧計測は連続血圧モニター（コーリン電子 株式会社 CBM 3000）を用い，仰臥位で通常血圧 を計測し，姿勢変化を加党，元にもどす，これら の繰り返しで行った。右手の同一橈骨動脈上に 近接して血圧用センサーと脈波計測部を装着し, マンシェット圧電気信号を基にして比較検討し た。

\section{結 果}

約 1 分間の 1 回の計測からは図 6 に示すよらな 特徵的な 3 つの紡錘形パターンが得られた。この 紡錘形の大きさ，長さ，配置に個人差があり，呼 吸性の振幅変動が入り込んでいた。中央には必ず 振幅増加に転ずる起始部が存在し, このマンシェ ット圧では中枢側はほぼ最大振幅となっていた。 




図 8 末梢側振幅増加起始部が中央より高圧で起こる場合の減圧過程と同期重福

また，末梢側にも同様の起始部が存在するが，出 現は不規則で一定傾向は見当たらなかった。

波形拡大による 3 チャンネル同期重祆書で減圧 過程を観察すると，図７の(A)に示すように中央の 振幅増加起始部に拈いて中枢側と中央の波形立ち 上がり点に常に時間差 $(\tau)$ が認められた。中枢側 飞対し中央は平均值 $37.3 \mathrm{msec}$ 標準偏差 $11.8 \mathrm{msec}$ $(\mathrm{N}=400)$ の時間遅れとなって和り, 図 7 の(B), (C)に示すように，この時間遅れはマンシェット圧 の低下に伴い減少し, ある圧以下では全例ともに 泳ぼ 0 となった。

腕の左右を考慮しない場合，健常人の腕の $84 \%$ は中央の振幅増加超始部に拈いて末梢側では圧伝 播による波形が観測されず，さらにマンシェット 圧が減圧してから末梢側振幅増加超始部が現われ
た。しかし，図８のよらに健常人に拈いて末梢側 振幅増加超始部が中央のそれより高圧で起こる場 合がある。この現象が観察された率は右腕のみは $11 \%$ 左腕の夕は $12 \%$, 両腕共は $8 \%,(\mathrm{~N}=100)$ の結果であった。このような場合, 中央の振幅増 加起始部に打いて中枢側と末梢側の波形立ち上が り点を同期重放書で比較観測すると, 末梢側の波 形立ち上がり点は中枢側に対し平均值 $50.5 \mathrm{msec}$ 標準偏差13.5msec $(\mathrm{N}=40)$ の時間遅れであった。 そして，この圧伝播は尺骨動脈を強圧迫すること で消失した。

血圧変化飞対するマンシェット圧電気信号の変 化を比較した結果, 中央振幅增加起始部でのマン シェット圧と最大血圧の相関係数は $0.97(\mathrm{~N}=10)$ であった。また，中枢側，中央の波形立ち上がり 
点時間差が 0 となる最大マンシェット圧と最小血 圧の相関係数は $0.93(\mathrm{~N}=10)$ と高值を示した。 しかし, 安静時にマンシェットの繰り返し装着を 行うと，両血圧と対応するマンシェット圧は一定 せず，巻き付け時の初期テンションに大きく依存 した。

\section{考 察}

中央の振幅増加起始部はマンシェットから与兄 られた中枢側センサーの押し圧と橈骨動脈最大血 圧の平衡点であり，この時の中枢側と中央の波形 立ち上がり点時間差は中枢側センサーで扁平にさ れた動脈の開口伝播時間を示し，センサー中心間 距離13mm から開口伝播スピードを求めることが できる。同時に中央センサーで得られる波形は開 口伝播によって歪んだ波形と言え，扁平血管内の 層流の性質が現われると思われた。また，このマ ンシェット圧での中枢側センサーの波形は, 中央 センサーの流入端で比血された状態での波形であ り, 流体力学的な全圧が動脈側圧として観測され たものである。したがって，呼吸性変動が無いと 仮定した場合，振幅は最大となる。この平衡状態 に沶いて，大多数例では末梢側へ血流が入り込ん で打らず，末梢側の波形は観測されない。しかし， 少数例であるが末梢側センサーに圧伝播が観測さ れる場合があった。浅手掌, 深手掌動脈弓を介し た尺骨動脈からの回り込みで，約 $2 \mathrm{~m} / \mathrm{sec}$ の圧伝 播スピードと算出でき，これらから動脈弓の開閉 が観察できた。

マンシェット圧がこの平衡点より低下すると， 中央, 末梢側へ順次血流が入り达み, 開口伝播ス ピードが次第に大きくなって行く。そして，つい には中枢側，中央の波形立ち上がり点時間差が注 ぼ 0 となる。この現象は, 中枢側センサーの押し 圧が橈骨動脈最小血圧と平衡し中枢側偏平血管内
が常時血液充填され，通常の圧伝播スピードであ る約 $10 \mathrm{~m} / \mathrm{sec}$ に到達し， $13 \mathrm{~mm}$ のセンサー中心 間距離では 0 として観測されたものと考えられ る。

\section{結 論}

指による脈診を機械化することは困難なことで ありそその手法のごく一部を実現し検討した。東 洋医学脈診（六部定位診法）での強圧迫『血流を 比め，指を緩めて行くときに始めて 3 指に触れを 感じるところ 』で捕捉可能な情報は，中枢側の 第四指は橈骨動脈血流の全圧情報であり，中央の 第三指は中枢側から開口伝播された薄層流の性質 であると推察された。さらに，末梢側の第二指は 浅手掌，深手掌動脈弓の開閉による尺骨動脈から の圧伝播の影響を強く受けると思われた。

謝辞 本稿の作製にあたり，御指導をいただきまし た渥美和彦先生，仁田新一先生，御校閲をいただきま した鈴木吉彦先生，御協力いただきました宮下明美さ ん，石松文枝さんに感謝いたます。

\section{文 献}

1) 丸山敏秋著: 黄帝内経と中国医学, 東京美術, 4 章, 189-194, 1988

2）白熙洙：特許公報, 昭57-52054

3 ) 費兆䅣: 中国脈診研究, 上海中医学院出版社, $78-118,1991$

4) 篠原鼎: 脈診の科学化の軌跡 2 , 医道の日本社, 第543号，99-103，1989

5) M.Takashima:Basic research on pulse diagnosis using a revolutionary new machine IASTAM, 576-584, 1994

6) 舟木寛伴著 : 脈診, その手法と古典的背景, 谷口 書店, 32-106, 1989

7 ）本間祥白著：難経の研究，医道の日本社，19-22, 1988

要旨 橈骨動脈を対象とした，東洋医学的脈診法を機械化した。指に代わる交流型の圧力七 ンサーを独自に開発し，3個のセンサーの押し当て方を検討した。その結果，各人各様の腕に 対して, 滑り機構付のマンシェットが最適かつ被験者の体動の影響を受けにくいことが確かめ られた。経験的な動脈の圧迫圧を回避する目的でマンシェット圧の連続減圧を行い，減圧過程 の信号の中から物理量を探り脈診法の科学的解明を試みた。血流が比まる充分な高圧から連続 
減压した場合, 各チャンネルの信号は压力変化に件って振幅が変化し, 全体で特徽的な振幅パ ターンが得られた。このパターンから，減圧に伴ってセンサー列の下へ順次拍動流が押し進む 様子が観察され, 中央側, 末梢側センサーに拍動流が到達したときの側圧変化, 開口伝播スピ ード，浅手掌，深手掌動脈弓の開閉が観測可能となった。 